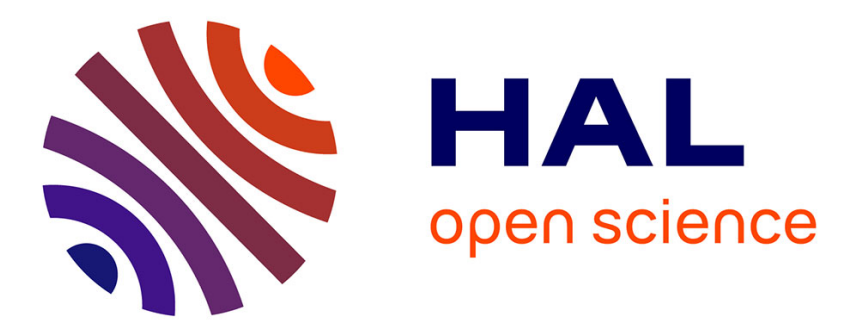

\title{
An Application of Operations Research for Reducing Fuel Costs
}

João Roberto Maiellaro, João Reis, Alexandre Formigoni, Robson Dos Santos, Marcos Oliveira, Celso Jacubavicius

\section{- To cite this version:}

João Roberto Maiellaro, João Reis, Alexandre Formigoni, Robson Dos Santos, Marcos Oliveira, et al.. An Application of Operations Research for Reducing Fuel Costs. IFIP International Conference on Advances in Production Management Systems (APMS), Sep 2016, Iguassu Falls, Brazil. pp.225-231, 10.1007/978-3-319-51133-7_27. hal-01615796

\author{
HAL Id: hal-01615796 \\ https://hal.inria.fr/hal-01615796
}

Submitted on 12 Oct 2017

HAL is a multi-disciplinary open access archive for the deposit and dissemination of scientific research documents, whether they are published or not. The documents may come from teaching and research institutions in France or abroad, or from public or private research centers.
L'archive ouverte pluridisciplinaire HAL, est destinée au dépôt et à la diffusion de documents scientifiques de niveau recherche, publiés ou non, émanant des établissements d'enseignement et de recherche français ou étrangers, des laboratoires publics ou privés.

\section{(c)(1)}

Distributed under a Creative Commons Attribution| 4.0 International License 


\title{
An Application of Operations Research for Reducing Fuel Costs
}

\author{
João Roberto Maiellaro ${ }^{1,2}$, João Gilberto M. dos Reis ${ }^{1}$, Alexandre Formigoni ${ }^{2}$, \\ Robson dos Santos ${ }^{2}$, Marcos A. M. de Oliveira ${ }^{2}$, and Celso Jacubavicius ${ }^{2}$ \\ 1 Paulista University, São Paulo, Brazil \\ 2 Faculdade de Tecnologia de Guarulhos, Guarulhos, Brazil \\ joao.maiellaro@fatec.sp.gov.br
}

\begin{abstract}
The objective of this work is to identify gas stations out of the route predeter-mined by a transport company based both on refueling feasibility and on lower fuel costs. The work consists of a case study that collected data such as kilome-ters run, amount refueled, product transported, type of operation, and average diesel consumption during the trip. Through the Operations Research, we were able to evaluate the feasibility of deviating the vehicle from the current route (mainly highways) to stations in the surroundings. The aim was to check if the organization would obtain any significant fuel cost reduction from this deviation. Our findings suggested cost reduction for the route used in the model, as well as the need to apply the mathematical model whenever there was an intention to deviate from the route in order to refuel at stations with lower diesel prices.
\end{abstract}

Keywords: Fueling · Operations Research · Cost Reduction · Gas Stations

\section{Introduction}

Consistently searching for cost reduction in all stages of the logistic process is a goal to be reached. Freight movement absorbs between one-third and two-thirds of logistics costs, and that is exactly why improving efficiency using the most of the transport equipment and personnel is one of the greatest concerns of the segment [1].

In Brazil, the current scenario of inflation, economic stagnation, and poor economic growth has been causing increased fuel prices, and eventually impacting the transport companies' operating costs, as well as other services relying on fuel and oil derivatives.

Based on this scenario and on the high fuel costs observed, we attempted to strategically evaluate how to reduce these costs in order to achieve profitability without affecting the operation and customer service.

To avoid any significant impact on the increased operating costs, it is necessary to get adapted and prepare a plan while seeking lower costs at the same time. To cut down operating costs, an organization has to adapt itself to the 
country's economic situation and prepare its operations aiming at the lowest costs possible. The Vehicle Routing and Scheduling (VRS) method is an important tool that many organizations that have been implementing this method through software applications in order to reduce the operating costs. The organization object of this study is engaged in transportation services and uses the VRS method to support the route planning process.

The objective of this work is to detect gas stations out of the route predetermined by a transport company based both on refueling feasibility and lower fuel costs.

\section{Methodology}

Stage one consisted of detecting the problem by observing transport related operations. To this end, we used reports extracted from an automated fueling control website, as well as dynamic spreadsheets and tables that are typically used to measure KPIs (Key Performance Indicators) used to assess a driver's award (prepared by the organization).

We also used reports extracted from the ERP system. Stage two consisted of collecting data from the organization regarding the management of financial costs with fuel, organizing such data into tables, and evaluating them. We used an online fuel management system that keeps record of the amount refueled and fuel price on a realtime basis, as well as of the location of each station on the route. For stage three, we assessed prices and refueling feasibility at stations where drivers are not authorized tore fuel their vehicles. To select these new stations, we used criteria such as local topography, infrastructure, and accessibility of the station. Stage four consisted of structuring the data into a mathematical model, taking into account the total kilometers of the route, tank capacity, average kilometers run per liter, and the location and prices of the selected stations.

\section{Case Study}

The organization object of this study has been present in the Brazilian market for 75 years providing road transportation services. Organizations must focus on providing its services with excellence, efficiency, and effectiveness and meeting their customers' requirements at low operating costs, for it sees both increased earnings and reduced costs as profit [2].

One of the operating costs comes from the fleet, that is the essence of a road transport organization, thus requiring full attention and dedication. The main fleet-related costs include tires, fuel, IPVA [Motor Vehicle Ownership Tax], driver's salary, lubricants, maintenance, tolling, and overheads. In this study, we focused on the fuel factor.

Transport sector is involved in a very competitive market and besides, it has been changing due the technological development e economic [3].

Among other factors, the amount of fuel to be consumed on a certain route depends on the distance, traffic, load weight, and $\mathrm{km} / \mathrm{l}$. 


\subsection{Defining the Problem}

The problem consists of determining the best option to refuel the vehicle during the trip, taking into account the cost and distance variables and the feasibility of deviating from the route to refuel at a station where the price per liter is cheaper, due to the fact that, by failing to look at these factors, usually only the liter price alone is taken into account, while the kilometers run and respective consumption associated with the deviation are left aside.

Main aspects of a problem are the exact description of the study objectives, identification of possible decision alternatives, and confirmation of the system limitations, restrictions, and requirements [4].

Within these aspects, we have as exact description of the study objectives the cheaper fuel costs. The possible decision alternatives would be the methods to solve this problem, while the confirmation of the limitations would be the vehicle and its capacities.

Our findings suggested that there is a need to study the causes of the high prices left aside and to propose solutions to cut down these costs. We collected the following data: routes used, load weight, vehicle model and capacity, location of each station and diesel price per liter.

The organization currently uses an automated fueling control website to determine what stations their drivers are authorized to stop by and refuel. This authorization is granted on a real-time basis, and the diesel price can be negotiated through the system. As a consequence, only the agreed-upon prices can be carried out by the parties.

We identified that many stations that are close to the routes currently used offer diesel at a more affordable price, but drivers are not authorized to refuel at these stations.

We selected the route from Campinas/SP to Catalão/GO because it has the highest diesel consumption and worst consumption performance of liter per kilometer run. The route holds over 200 trips every month. With the help of Google Maps - Figure 1 - we could see that the way to this route, through the BR-050 highway, is $601 \mathrm{~km}$ long.

Based on Table 1, it is concluded that a truck with full tank can run at most $392.6 \mathrm{~km}$. This means that it will need to refuel during the trip. To avoid any incidents, the organization requires drivers not to use a vehicle with less than $1 / 4$ of the tank, thus making it necessary to scheduler fueling at intervals of approximately $300 \mathrm{~km}$.

The load being carried consists of automotive parts, and we considered the vehicle operating at its maximum capacity. The customer from Catalão wanted the transportation to be carried out by a Mercedes-Benz truck Axor 2644 model. Hence, it was possible to address the study as a function of the truck functional characteristics [5], as listed in Table 1.

The value of $(\mathrm{t} \times \mathrm{km}) / \mathrm{l}$ was obtained by evaluating the fuel consumption history of this type of truck in February of 2015, where it showed a general average of $\mathrm{t} x \mathrm{~km} /$ liter $=1.963$, according to Table 2 . 


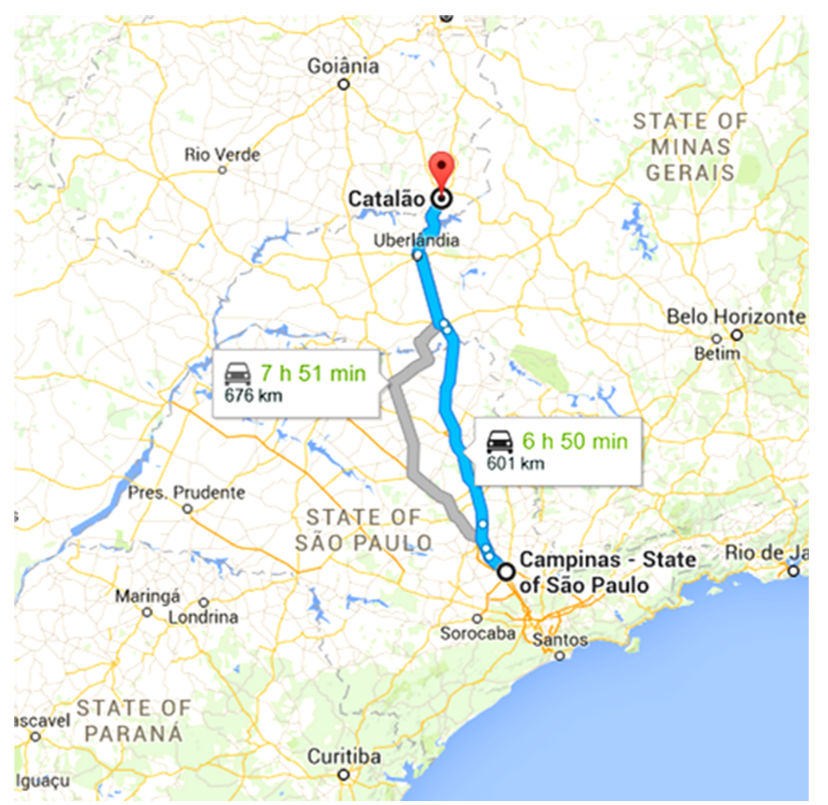

Fig. 1. Route from Campinas to Catalão

Table 1. Truck Specification: Mercedes-Benz/Axor 2644

\begin{tabular}{cccc}
\hline LOAD & TANK & MAX. & Tons X Km / l \\
& CAPACITY (l) LOAD (tons) & \\
\hline EMPTY & 200 & 40 & 2.3 \\
FULL & 200 & 40 & 1.963 \\
\hline
\end{tabular}

Table 2. $(\mathrm{t} \times \mathrm{km}) /$ liter

\begin{tabular}{ccccc}
\hline Manuf. Year & Model & Branch & $\mathrm{t} \mathrm{x} \mathrm{km} \mathrm{/}$ & Fuel \\
\hline 2014 & AXOR 2644 CATALÃO & 1.99 & Diesel \\
2014 & AXOR 2644 CATALÃO & 2.15 & Diesel \\
2014 & AXOR 2644 CATALÃO & 1.75 & Diesel \\
2014 & AXOR 2644 CATALÃO & 1.60 & Diesel \\
2014 & AXOR 2644 CATALÃO & 1.97 & Diesel \\
2014 & AXOR 2644 CATALÃO & 2.09 & Diesel \\
2014 & AXOR 2644 CATALÃO & 1.86 & Diesel \\
2014 & AXOR 2644 CATALÂO & 1.89 & Diesel \\
2014 & AXOR 2644 CATALÃO & 1.95 & Diesel \\
2014 & AXOR 2644 CATALÃO & 2.38 & Diesel \\
\hline
\end{tabular}


Based on intervals of $300 \mathrm{~km}$, with the help of Google Maps, we can see that on this route, the vehicle will pass through region of Guará and Ituverava São Paulo's inland cities, and the organization has agreements with gas stations of both these cities located on the highway. The methods described in this work were applied to the city of Guará while trying to respect the most of the interval limits.

\subsection{Building the Model}

To build the model, we needed details on the data used, an oriented graph, and mathematical modeling using linear programming principles.

We took infrastructure and accessibility into account to select the stations in a maximum distance of $4 \mathrm{~km}$ from the road. Table 3 shows the data defining the actual price (AP) for each leg of the trip, i.e., the address of each station, its distance from the route (each way), and the fuel price per liter at each station. The Santo Expedito gas station is the one currently used, so there are no route deviations to get to it.

Table 3. Adresses, distances and prices

\begin{tabular}{|c|c|c|c|c|}
\hline $\begin{array}{c}\text { Trading Name } \\
\text { Gas station }\end{array}$ & Address & $\begin{array}{c}\text { Way } \\
\text { In }(\mathrm{km})\end{array}$ & $\begin{array}{c}\text { Way } \\
\text { Out }(\mathrm{km})\end{array}$ & Diesel BRL/1 \\
\hline Santo Expedito & Anhanguera, Km 395 & 0 & 0 & 2.869 \\
\hline Maranatha & Voluntários de Guará, 597 & 2.2 & 2 & 2.699 \\
\hline Guara & Duque de Caxias, 746 & 2.9 & 1.3 & 2.728 \\
\hline Avenida & Quinze de Setembro, 31 & 3.1 & 1 & 2.800 \\
\hline
\end{tabular}

The branch of Campinas starts the trip after filling up at the Frango Assado gas station, at BRL 2.999 per liter. By applying these data to the formulas, the AP can be obtained, as listed in Table 4.

Table 4. Ap structuring

\begin{tabular}{|c|c|c|c|c|c|c|c|c|}
\hline $\begin{array}{l}\text { Trading } \\
\text { Name }\end{array}$ & $\begin{array}{c}\text { Tank } \\
\text { (1) }\end{array}$ & $\begin{array}{l}\text { BRL } \\
\text { per } \\
\text { liter }\end{array}$ & $\begin{array}{c}\text { Deviation } \\
\text { to the } \\
\text { Station } \\
(\mathrm{km})\end{array}$ & $\begin{array}{c}\text { Liter } \\
\text { Price in } \\
\text { the Last } \\
\text { Refueling }\end{array}$ & AP1 & $\begin{array}{c}\text { Return } \\
\text { to the } \\
\text { Highway } \\
(\mathrm{km})\end{array}$ & AP2 & TOTAL \\
\hline P1 Santo Expedito & 200 & 2.86 & 0 & 2.999 & 573.8 & 0 & 0.0 & 573.80 \\
\hline P2 Maranatha & 200 & 2.69 & 2.2 & 2.999 & 543.1 & 2 & 2.75 & 545.91 \\
\hline P3 Guara & 200 & 2.72 & 3.1 & 2.999 & 550.3 & 1.3 & 1.81 & 552.14 \\
\hline P4 Avenida & 200 & 2.80 & 3.4 & 2.999 & 565.1 & $\begin{array}{c}1 \\
(\mathrm{t} \times \mathrm{km}) / \mathrm{l}\end{array}$ & 1.43 & $\begin{array}{c}566.62 \\
1963\end{array}$ \\
\hline
\end{tabular}


The linear programming model considered as the objective function the minimization of fuel cost, and constraints were related to origin and possible destinations. Constraints ensured that vehicle had only one origin for each destination and ensured that vehicle had not more than one destination for each origin on the route.

\subsection{Results and Discussion}

To solve the problem, it was used the software LINDO 6.1, due its nature, which consists of a minimum path problem. This group involves combinatory analysis problems, and the number of possible solutions is 5040 combinations and only one is optimal.

Station P2 showed a total cost of BRL 545.91 with fueling to the route/type of distribution being studied, road topography restrictions, bridges with height restrictions, narrow streets where big vehicles cannot running time, i.e., $4.86 \%$ less than the cost of the current station. This method had a positive impact on the decision of the best option to refuel.

In another application, the percentage reduction will subsequently vary according get past. As previously stated, this method serves to evaluate and support the decision, thus, occasionally a station with which the organization already has an agreement may lead to greater cost-effectiveness. However, we concluded that the proposed scenario, with routes from Campinas/SP to Catalão/GO, suggested a significant reduction, considering that this trip is repeated 200 times/month in average, i.e.:

$200 \times 573.80=114,760-4.86 \%=109,182.67 ;$ a reduction of over BRL 5.5 thousand.

\section{Conclusions}

This study presents a study to identify new partner ships between the organization and its potential suppliers. Therefore, this study should be extended to other routes. The model will be subsequently adapted for Road Distribution operations, where the route goes from the city of Duque de Caxias, in Rio de Janeiro State, to the city of Campina Grande, in Paraíba State, in addition to several other routes that need to be evaluated.

The study shows that, with correct evaluation, a small deviation from the route to refuel at a lower price may have a big impact on the reduction of fuel costs. The proposed method is based in a traditional Operations Research' tools in the sense that it can be adapted to different situations, to longer or shorter distances, to any demographic region, and to any type of fuel and vehicle.

\section{References}

1. Ballou, R.H.: Business Logistics/Supply Chain Management: Planning, Organizing, and Controlling the Supply Chain. Pearson/Prentice Hall, Upper Saddle River (2004) 
2. Slack, N., Chambers, S., Johnston, R.: Administração da Produção. Atlas, São Paulo (2002)

3. Novaes, A.G., Valente, A.M., Passaglia, E., Vieira, H.: Gerenciamento de Transporte e Frotas. Cengage Learning (2008)

4. Hillier, F.S., Lieberman, G.J.: Introdução à Pesquisa Operacional. AMGH, Porto Alegre (2013)

5. Mercedes-Benz do Brasil: https://www.mercedes-benz.com.br/caminhoes/axor/ dados-tecnicos 